\title{
PERANCANGAN DESAIN USER INTERFACE DAN USER EXPERIENCE PADA APLIKASI JASA PENGANGKUTAN SAMPAH TRASH CARE
}

\author{
Rijois I. E. Saragih, Risda R. Pangaribuan*, Tiurma C. Naomi, Gorbyno Sitepu, Desty \\ Siregar, Yanti L. Sibarani, Wiwi Ginting, Enda M. Pinem \\ Universitas Methodist Indonesia \\ Email: *risdarebeka@gmail.com
}

DOI: https://doi.org/10.46880/jmika.Vol4No1.pp47-55

\begin{abstract}
ABSTRAK
Seiring perkembangan zaman, produksi sampah setiap hari semakin meningkat. Ini disebabkan karena, bertambahnya jumlah produk, jumlah penduduk dan pola konsumsi masyarakat. Selain itu, kurangnya tingkat kesadaran masyarakat untuk membuang sampah pada tempatnya yang dapat mengakibatkan tingginya tingkat pencemaran lingkungan. Contohnya, di Kota Medan yang menghasilkan timbulan sampah setiap harinya sebesar 2.000 ton/hari. Kota Medan merupakan kota yang mendapatkan dampak dari tidak adanya pengelolaan sampah yang baik. Hal yang harus dilakukan untuk mengatasi peningkatan volume sampah tersebut adalah dengan cara mengurangi volume sampah dari sumbernya melalui pengelolaan sampah. Hadirnya android dapat memudahkan kegiatan sehari - hari seperti adanya aplikasi Trash Care yang dapat membantu dalam menanggulangi sampah. Penelitian ini berfokus pada perancangan desain user interface(UI) dan user experience (UX) aplikasi Trash Care yang berdasarkan pada kemudahan, efisiensi, dan kegunaan untuk pengguna. Penelitian ini menggunakan metode UCD dalam menjelaskan alur Aplikasi Trash Care dan metode pengumpulan datanya dengan menggunakan dokumentasi. Hasil dari penelitian ini adalah berupa desain interface aplikasi yang disesuaikan dengan kebutuhan pengguna. Adanya desain user interface aplikasi mobile ini diharapkan dapat meningkatkan minat pengguna dalam membuang sampah dan dapat menambah pengetahuan masyarakat dalam membedakan sampah organik dan anorganik.
\end{abstract}

Kata Kunci: Android, Trash Care, Organik, Inorganik, User Interface, User Experience

\section{PENDAHULUAN}

Seiring dengan meningkatnya pertumbuhan ekonomi maka semakin besar tingkat konsumtif masyarakat. Manusia dalam mengkonsumsi dan memanfaatkan sumber daya alam tidak lagi hanya sekedar untuk hidup dan sesuai dengan kebutuhan tapi sudah lebih dari sekedar memenuhi tuntutan gaya hidup, yang mengakibatkan banyaknya barang-barang tidak terpakai yang dapat merusak lingkungan hidup. Sampah adalah suatu bahan yang terbuang dari sumber hasil aktivitas manusia maupun proses alam yang belum memiliki nilai ekonomis (Suriawiria, 1986). Pertambahan jumlah sampah yang tidak diimbangi dengan pengelolaan yang ramah lingkungan akan menyebabkan terjadinya perusakan dan pencemaran lingkungan (Sulistiyorini, 2015). Masalah yang ditimbulkannya dapat meliputi barbagai hal, terutama kesehatan dan sosial ekonomi.

Pertumbuhan jumlah sampah di kota-kota di Indonesia setiap tahun meningkat secara tajam. Sebagai contoh di Kota Medan. Kota Medan merupakan kota metropolitan ketiga setelah Jakarta dan Surabaya dan pasti mempunyai permasalahan persis sama yaitu masalah persampahan kota. Jumlah penduduk Kota Medan
2.210.624 jiwa yang menghasilkan timbulan sampah setiap harinya sebesar 2.000 ton/hari. Produksi sampah tersebut yang mampu diangkut oleh Dinas Kebersihan Kota Medan baru $68 \%$, sedangkan $32 \%$ belum terangkut.Berdasarkan data Suku Dinas Kebersihan Kota Medan (2014) adanya sampah yang tidak terangkut di sebabkan karena kurangnya armada angkutan (Rahayu, 2019).

Dengan meningkatya kebutuhan masyarakat dibidang teknologi yang semakin canggih kita dapat memanfaatkannya untuk membantu pengolahan sampah. Salah satunya melalui android. Oleh karena itu, penelitian ini akan membuat user experience dan user interface sebuah aplikasi jasa pengangkutan sampah berbasis android yang bernama Trash Care yang dirancang sesuai dengan keinginan pengguna dan kemudahan dalam penggunaan aplikasi yang dapat membantu masyarakat untuk mempermudah pengambilan sampah. Selain itu, mengajarkan kepada masyarakat bahwa sampah organik dan anorganik itu berbeda. Bukan itu saja, masyarakat juga akan mendapatkan untung ketika mereka melakukan transaksi pemesanan sampah anorganik. 


\section{STUDI LITERATUR}

\section{User Interface}

Selain aspek estetika yang tampak secara visual, desain user interface harus dapat menyampaikan fungsinya. Menurut studi Nielsen, usability adalah tujuan akhir dari desain user interface. Komponen yang menentukan usability sebuah desain adalah kemudahan untuk dipelajari, efisiensi, ingatan pengguna terkait fungsi aplikasi setelah beberapa kali menggunakan, kesalahan yang dilakukan pengguna, dan kepuasan pengguna (Rianingtyas, 2018).

\section{User Experience}

User experience berkaitan dengan apa yang dirasa oleh pengguna yang berhubungan dengan kemudahanan, kenyamanan, efisiensi, kemanfaatan saat menggunakan halaman sebuah website atau aplikasi (Naser, 2018).

\section{Aplikasi Mobile}

Untuk menentukan jenis aplikasi yang akan dibuat diperlukan informasi mengenai jenis aplikasi mobile yaitu aplikasi native, aplikasi web, dan aplikasi hybrid. Dari analisis tentang kelebihan, kekurangan, dan kesesuaian dengan konsep perancangan sehingga aplikasi native adalah yang akan dikembangkan. Salah satu kelebihannya adalah optimalisasi pengalaman yang akan didapatkan oleh pengguna melalui grafis, gambar, skrip dan data aplikasi (Rianingtyas, 2018).

\section{Sampah}

Menurut Davis dan Cornwell (2008: 737) menjelaskan bahwa kata sampah padat merupakan suatu kata yang umum digunakan untuk menggambarkan sesuatu yang kita buang. Jika dibiarkan maka dapat merusak lingkungan.

Salah satu upaya untuk dapat menyelesaikan permasalahan sampah adalah dengan melakukan pengelolaan sampah yang bisa dilakukan dengan prinsip 3R (reduce, reuse, dan recycle). Langkah utama adalah pemilihan sejak dari sumber. Pemilihan adalah memisahkan antara jenis sampah yang satu dengan jenis yang lainnya. Minimal pemilihan menjadi dua jenis:

a. Sampah organik, yaitu sampah yang tidak dapat di daur ulangyang dapat dirubah menjadi kompos yang bernilai seperti sayur, buah-buahan, dan sebagainya.

b. Sampah non-organik, yaitu sampah yang dapat di daur ulang menjadi benda/barang lain yang dapat bermanfaat kembali seperti plastik, kaca, logam, dan sebagainya (Sulistiyorini, 2015).

\section{METODE PENELITIAN \\ Metode Pengumpulan Data}

Dalam pengumpulan data penulisan menggunakan dokumentasi. Dokumentasi adalah mencari data mengenai hal-hal atau variabel yang berupa catatan,buku,surat kabar, majalah prasasti, notulen rapat, lengger, agenda, internet dan sebagainya. Dalam penulisan ini digunakan untuk mencari data yang dibutuhkan yang berhubungan dengan kebutuhan pengguna dalam menggunakan aplikasi ini.

\section{Alur Penelitian}

Teknik analisis data adalah upaya yang dilakukan dengan jalan bekerja dengan data, mengorganisasikan data, memilah-milah menjadi satuan yang dapat dikelola, mengsintesiskannya, mencari dan menemukan pola, menemukan apa yang penting dan apa yang dipelajari, dan memutuskan apa yang dapat diceritakan kepada orang lain. Oleh karena itu kami menggunakan alur dari metodologi penelitian ini dengan menggunakan metode UCD dalam menjeslakan aplikasi Trash Care.

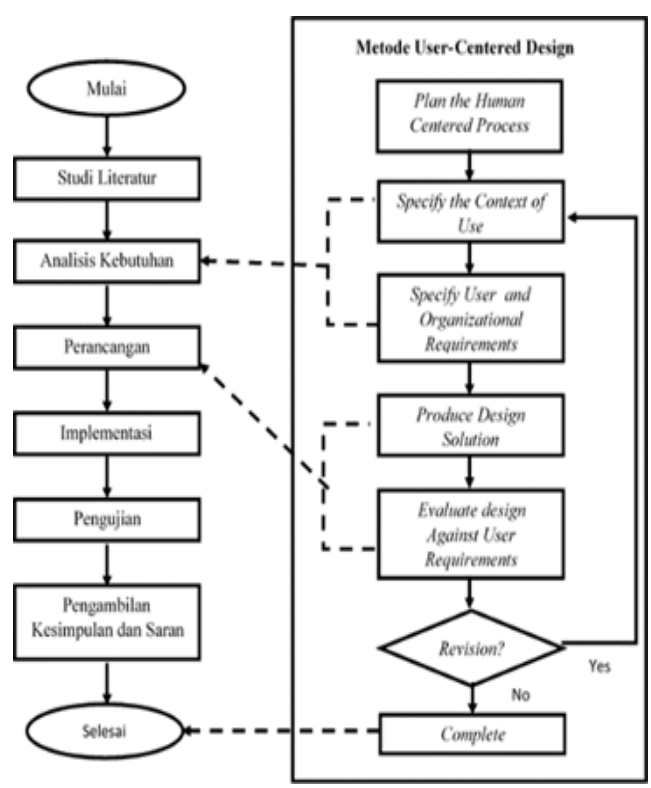

Gambar 1. Tahapan penelitian

Alur Metode UCD yang pertama ialah specity the context of use, yang dimana dalam melakukan identifikasi dan menentukan siapa calon pengguna aplikasi. Setelah itu terdapat tahap specify user and organizational requirement untuk mengidentifikasi apa saja kebutuhan dari calon pengguna aplikasi, tahap ini dilakukan dengan wawancara kepada 2 orang pengumpul sampah. Tahap perancangan dilakukan setelah selesai melakukan 
proses analisis kebutuhan. Perancangan ini terbagi menjadi dua tahap yaitu perancangan sistem dan perancangan perangkat lunak. Dengan menggunakan metode UCD maka tahapan tersebut menyesuaikan dengan tahapan pada metode yang digunakan, yaitu pada alur product design solution dan evaluate design against requirements. Pada alur design solution peneliti membuat perancangan antarmuka berdasarkan hasil dari analisis kebutuhan. Tahap ini dilakukan untuk memberikan kemudahan bagi penggunanya dalam pengimplementasi aplikasi Trash Care. Apakah sudah sesuai atau belum dan disini terjadilah iterasi, jika belum sesuai peneliti harus memberbaiki sistem yang dibuat berdasarkan pada hasil evaluasi yang diberikan oleh calon pengguna. Perancangan yang dilakukan ini berdasar pada objectoriented programming dengan menggunakan flowchart. Perancangan yang dilakukan adalah perancangan arsitektur sistem, perancangan diagram sequence, perancangan basis data dan perancangan antarmuka beserta screenflow-nya. Setelah semua iterasi pada evaluasi design prototype selesai, langkah selanjutnya yang akan diambil adalah tahap implemetasi. Implementasi diawali dengan mengetahui spesifikasi yang dibutuhkan dalam membangun sistem tersebut, tidak hanya spesifikasi perangkat lunak saja tapi juga spesifikasi perangkat keras. Kemudian juga dijelaskan batasan-batasan masalah yang terjadi saat melakukan implementasi sistem. Dengan adanya pengujian maka akan didapatkan segala kekurangan dari sistem yang dibuat dan mengetahui apa saja yang harus diperbaiki untuk kedepannya pada sistem, sehingga isi hasil dari pengujian ini akan dijadikan sebagai isi dari kesimpulan dan saran.

\section{HASIL DAN PEMBAHASAN}

Target Pengguna

Aplikasi Trash Care merupakan aplikasi pengangkutan sampah berbasis android. Aplikasi ini bertujuan untuk memudahkan user dalam menangani masalah sampah khususnya di Kota Medan. Selain itu, aplikasi ini membantu Dinas Kebersihan Kota Medan dalam menangani masalah sampah melalui fitur yang ada, yaitu fitur Trash dan Picture. Secara tidak langsung, aplikasi ini memberikan pengetahuan kepada masyarakat dalam membedakan sampah organik dan sampah anorganik dan dapat memberikan tambahan saldo kepada masyarakat yang telah menjual sampah anorganik. Yang menjadi target utama dalam penggunaan aplikasi ini adalah masyarakat umum di Kota Medan yang ingin membuang sampah namun tidak memiliki waktu luang untuk membuangnya ke TPA.

\section{Batasan Sistem}

Aplikasi ini hanya membantu user dalam pengangkutan sampah yang sudah dibedakan dalam dua kategori, yakni organik dan anorganik. Selain itu, hanya dapat memberikan informasi kepada Dinas Kebersihan Kota Medan mengenai letak lokasi tumpukan sampah yang tidak terangkut melalui laporan user dengan menggunakan fitur Picture. Saat ini, aplikasi ini hanya dapat digunakan di Kota Medan. Desain sistem yang dibuat dilihat dari sudut pandang user atau masyarakat umum.

\section{Platform yang Digunakan}

Penelitian ini menggunakan aplikasi Adobe XD CC versi 18.2.12.2, Material Icons Google, UI Kit Wireframes Mobile, UI Kit Material Design dalam mendesain aplikasi Trash Care. Alasan kami menggunakannya, yakni :

1. Mudah digunakan dalam mendesain user interface/user experience

2. Memiliki fitur yang cukup baik

3. Dapat mendukung fitur tambahan

\section{Fast performance}

\section{Perancangan Sistem}

Proses penggunaan aplikasi Trash Care dimulai dari membuat akun, login, dan melakukan transaksi dapat dilihat pada Gambar 2. 


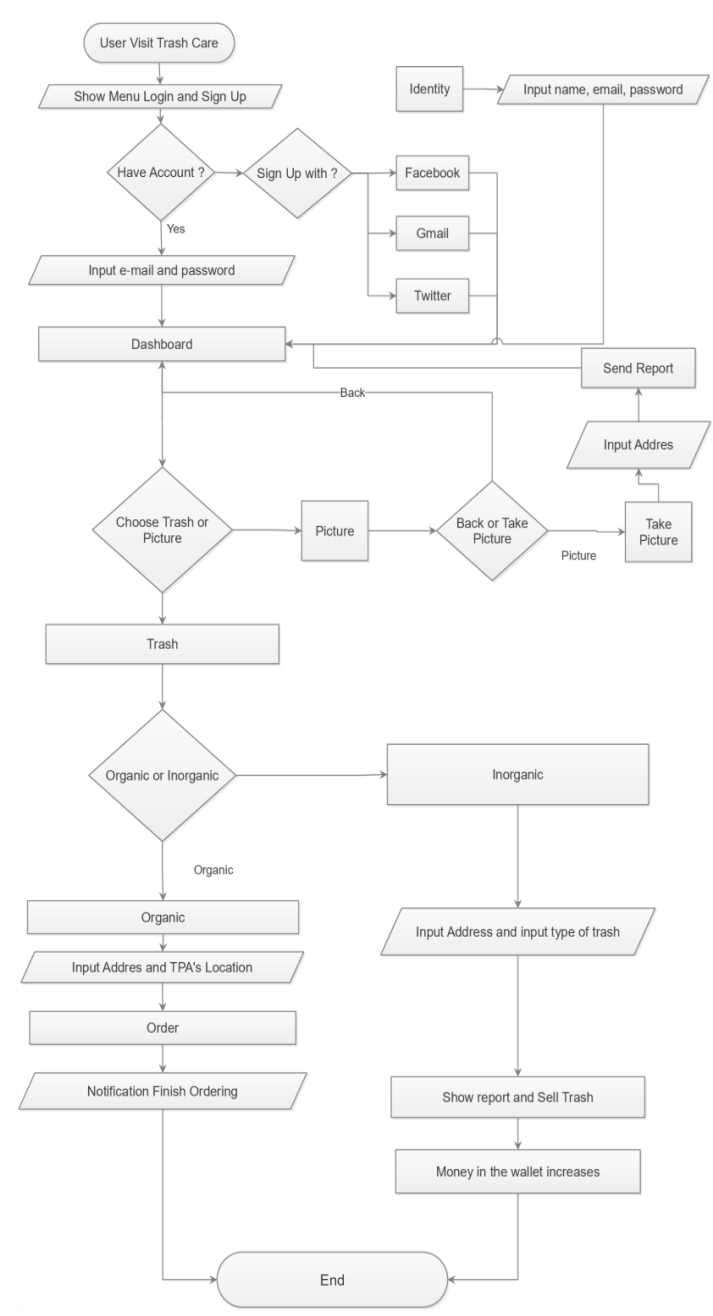

Gambar 2. Flowchart aplikasi Trash Care

\section{Skenario Penggunaan Rancangan Sistem}

Christian merupakan mahasiswa salah satu universitas di Kota Medan yang sibuk dengan perkuliahannya dan organisasi yang diikutinya. Akibat dari kesibukannya, sisa dari makanan dan barang yang tidak terpakai di kos semakin bertumpuk karena ia tidak memiliki waktu untuk membuang sampah dan jasa pengangkutan sampah yang ia bayar tiap bulan selalu datang terlambat. Oleh karena itu, Christian membutuhkan aplikasi jasa pengangkutan sampah untuk membantunya dalam pengangkutan sampah.

Christian mulai masuk ke aplikasi pengangkutan sampah Trash Care. Maka, Christian akan melihat tampilan splash screen. Dan dia akan menekan tombol Start Your Travel untuk masuk ke halaman login. Karena Christian adalah pengguna baru maka ia melakukan registrasi pengguna dengan mengisi kolom nama lengkap, e-mail dan password. Selain itu, Christian dapat registrasi melalui Facebook, Twitter, ataupun Gmail. Jika Christian sudah memiliki akun, ia tidak perlu lagi melakukan registrasi, ia dapat melakukan login dengan mengisi kolom e-mail dan password yang telah digunakan pada saat registrasi. Setelah itu, Christian dihadapkan dengan menu utama yang memiliki beberapa fitur yaitu Trash, Capture, serta informasi saldo yang ia miliki. Christian memiliki dua jenis sampah, yaitu organik dan anorganic.

Ketika Christian ingin melakukan pemesanan pengangkutan sampah, maka Christian memilih fitur Trash. Pada fitur Trash, Christian akan dihadapkan dengan dua pilihan jenis pengangkutan sampah yaitu, organic dan inorganic. Sampah yang diingin dibuang oleh Chrstian terlebih dahulu adalah sampah inorganic. Maka Christian memilih fitur inorganic. Setelah itu, Christian akan dihadapkan dengan halaman inorganic, disini Christian diminta untuk mengisi alamat rumah dan jenis sampah inorganic yang akan diangkut yang akan diangkut oleh driver Trash Care. Setelah Christian mengisi alamat dan jenis sampah inorganic yang akan diangkut, dia melakukan proses pengangkutan atau penjualan sampah dengan menekan tombol Sell Trash. Christian menemukan driver yang akan mengangkut sampahnya dan dia menunggu driver tersebut tiba di kosnya. Ketika driver sudah tiba di kosnya, maka Christian dan driver akan menimbang berat sampah yang akan diangkut. Jika sampah tersebut sudah ditimbang maka driver akan memasukkan informasi sampah yang akan diangkut. Selanjutnya, Christian membuka aplikasi Trash Care dan dia melihat informasi sampah yang akan dia buang berupa jenis sampah dan total harga yang akan dia buang atau jual yang telah di masukkan oleh driver pada halaman payment. Karena informasi pengangkutannya sudah sesuai maka Christian melakukan proses pengangkutan dengan menekan tombol Sell Trash. Dari proses pengangkutan sampah inorganic tersebut, sampah yang dia miliki sudah diangkut dan saldo virtual Christian bertambah yang dapat dia lihat pada menu Dashboard. Christian masih memiliki sampah organic yang ingin ia buang. Oleh karena itu, Christian memilih fitur Trash yang organic.

Ketika Christian memilih fitur organic, maka dia dihadapkan dengan halaman organic, pada halaman ini Christian mengisi alamat rumah dan alamat atau lokasi TPA. Ketika Christian mengisi kedua data tersebut, maka nanti Christian dapat melihat biaya pengangkutan yang akan dia bayar. Pada proses pemesanan, Christian dihadapkan dengan dua metode pembayaran yaitu metode cash dan metode saldo virtual. Karena Christian memiliki saldo virtual dan saldonya cukup untuk melakukan pembayaran organic. Maka, Christian memilih metode 
pembayaran dengan menggunakan saldo virtual dengan menekan tombol yang ada gambar dompet. Sampah organic-nya sudah diangkut oleh driver, Christian akan dihadapkan pada proses pengangkutan sampah organic dan pada halaman tersebut dia dapat melihat informasi bahwa saldo yang dimilikinya akan dipotong sesuai dengan biaya pengangkutan. Ketika Christian sedang berjalan - jalan dengan temannya, dia melihat bahwa lokasi yang dilewati penuh dengan sampah yang berserakan. Awalnya dia bingung ingin melaporkannya kepada siapa. Namun, Christian ingat pada saat ia membuang sampah dengan aplikasi Trash Care, dia melihat ada fitur Capture dan kamera yang disediakan oleh aplikasi tersebut untuk memberikan laporan mengenai lokasi penumpukan sampah yang akan diangkut oleh Dinas Kebersihan Kota Medan. Ia pun membuka aplikasi Trash Care.

Christian memilih fitur Capture, lalu dia mengambil foto sampah yang menumpuk tersebut dengan menekan tombol kamera. Lalu, dia mengisi alamat lokasi tersebut dengan menekan Share Location. Maka akan tampil alamat lokasi penumpukan sampah dan dia memilih tombol Send untuk mengirim laporan tersebut.

Tabel 1. Spesifikasi Fungsional fungsi Aplikasi Jasa Pengangkutan Sampah Trash Care

\begin{tabular}{|c|c|c|}
\hline No & Fungsi & Spesifikasi \\
\hline 1 & Trash & $\begin{array}{l}\text { Aplikasi Trash Care } \\
\text { memfasilitasi pengguna } \\
\text { untuk melakukan dua jenis } \\
\text { pengangkutan sampah, yaitu } \\
\text { sampah organic dan sampah } \\
\text { inorganic. }\end{array}$ \\
\hline 2 & $\begin{array}{l}\text { Metode Pembayaran } \\
\text { Sampah Organic }\end{array}$ & $\begin{array}{l}\text { Aplikasi Trash Care } \\
\text { menyediakan dua jenis } \\
\text { metode pembayaran, yaitu } \\
\text { secara cash atau dengan } \\
\text { menggunakan saldo virtual. }\end{array}$ \\
\hline 3 & Saldo Virtual & $\begin{array}{lr}\text { Aplikasi Trash } & \text { Care } \\
\text { memberikan saldo } & \text { virtual } \\
\text { kepada pengguna } & \text { ketika } \\
\text { melakukan } & \text { proses } \\
\text { pengangkutan } & \text { sampah } \\
\text { inorganic. } & \end{array}$ \\
\hline 4 & Capture dan Kamera & $\begin{array}{lr}\text { Aplikasi Trash } & \text { Care } \\
\text { memfasilitasi pengguna } \\
\text { untuk melaporkan lokasi } \\
\text { penumpukan sampah yang } \\
\text { akan disampaikan kepada } \\
\text { Dinas Kebersihan Kota } \\
\text { Medan }\end{array}$ \\
\hline 5 & Settings & $\begin{array}{l}\text { Aplikasi Trash } \text { Care } \\
\text { menyediakan layanan ubah } \\
\text { profil diantaranya nama } \\
\text { lengkap, alamat, email dan } \\
\text { kata sandi pengguna. Selain }\end{array}$ \\
\hline
\end{tabular}

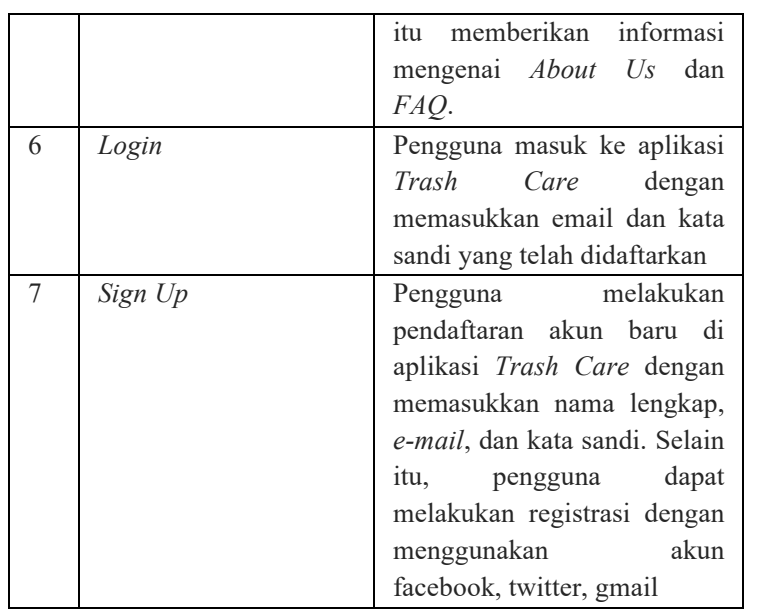

\section{Mekanisme Pengelolaan Sampah Dengan Aplikasi Trash Care}

Trash Care merupakan aplikasi pengangkutan sampah berbasis android. Adapun mekanisme pengelolaan sampah dengan aplikasi Trash Care sebagai berikut :

1. User mempunyai sampah rumah tangga yang akan diangkut dengan Trash Care

2. User melakukan pemilihan dan pembersihan sampah yang nantinya akan diangkut dengan Trash Care. Pemilihan dilakukan dengan cara memisahkan sampah berdasarkan jenisnya. Apakah itu sampah organik atau anorganik. Karena setiap sampah memiliki harga yang berbeda - beda dan tempat pengolahan yang berbeda.

3. Jika sampah organik maka sampah itu akan diangkut ke TPA dan tarif akan dikenakan sesuai dengan jarak lokasi TPA yang dipilih dan jika sampah anorganik maka sampah yang telah di pilah ditimbang oleh petugas Trash Care sesuai dengan harga yang telah ditetapkan.

4. Hasil timbangan sampah anorganik di input kedalam sistem oleh petugas untuk mengetahui jumlah saldo yang akan diberikan ke user.

5. Kumpulan sampah dari user yang terkumpul akan diambil untuk didaur ulang oleh Trash Care sesuai dengan kebutuhan.

\section{Desain User Interface Aplikasi Trash Care}

Pada tahap ini akan dijelaskan mengenai penggunaan aplikasi mulai dari user membuka aplikasi hingga mengakses setiap informasi yang ada dan menjalankan fitur yang disediakan aplikasi.

1. Tampilan Splash Screen

Saat user pertama kali mendownload dan menggunakan aplikasi Trash Care, maka 
halaman pertama yang diperlihatkan berupa identitas dari aplikasi tersebut.

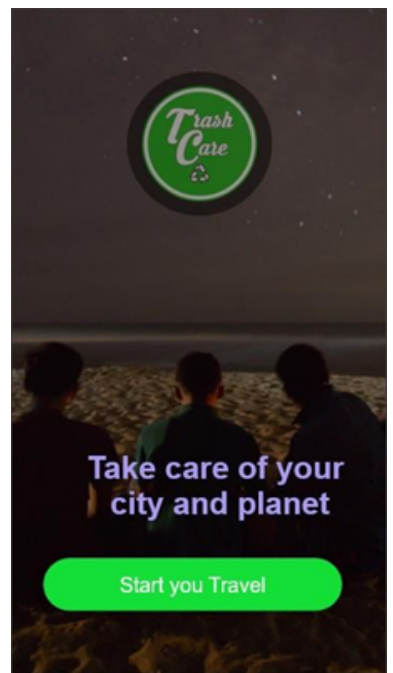

Gambar 3. Tampilan splash screen

2. Tampilan Login

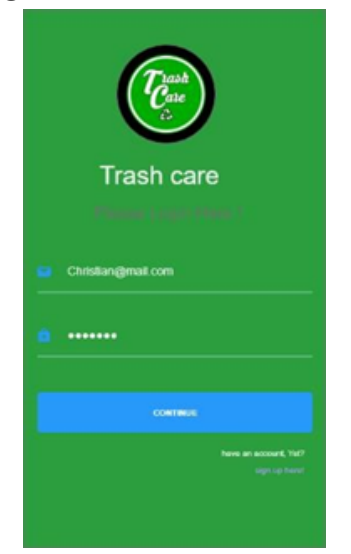

Gambar 4. Tampilan login

Menu ini merupakan halaman login yang ditampilkan ketika user pertama kali membuka aplikasi. Pada halaman login ini terdapat beberapa tombol antara lain :

a. Continue

Jika user sudah memiliki akun maka user dapat login ke sistem dengan mengisi $e$ mail dan password.

b. Sign Up Here

Jika user belum memiliki akun maka user terlebih dahulu membuat akun baru dengan mengklik Sign Up Here. Ketika user memilih Sign Up Here, maka user akan masuk ke halalaman pendaftaran akun.

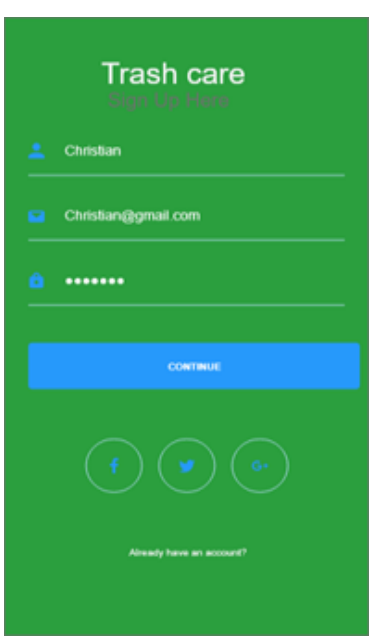

Gambar 5. Tampilan pendaftaran

Pada halaman ini, user dapat login melalui akun Facebook, Twitter, Gmail. User juga dapat mendaftar dengan cara mengisi data berupa nama, e-mail, dan password. Setelah data telah diinput dan user memilih tombol Continue maka akun baru telah berhasil dibuat dan user akan masuk ke Menu Utama.

3. Tampilan Menu Utama

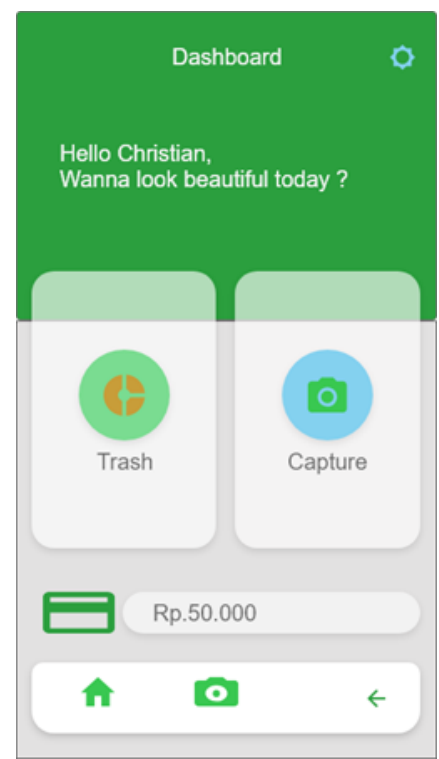

Gambar 6. Tampilan menu utama

Menu utama ini merupakan halaman utama yang ditampilkan ketika user sudah login. Pada halaman menu (Dashboard) terdapat informasi mengenai saldo user dan beberapa pilihan menu yang dapat dipilih oleh user antara lain :

a. Menu Trash

Pada menu Trash terdapat 2 menu pilihan, yakni Organic dan Inorganic. 


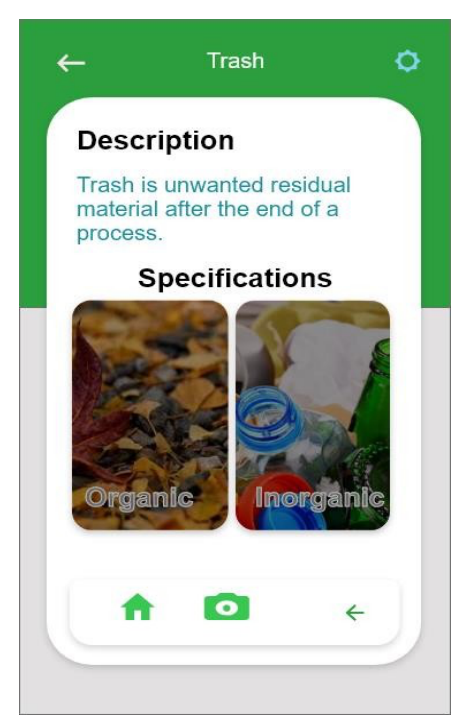

Gambar 7. Tampilan menu trash

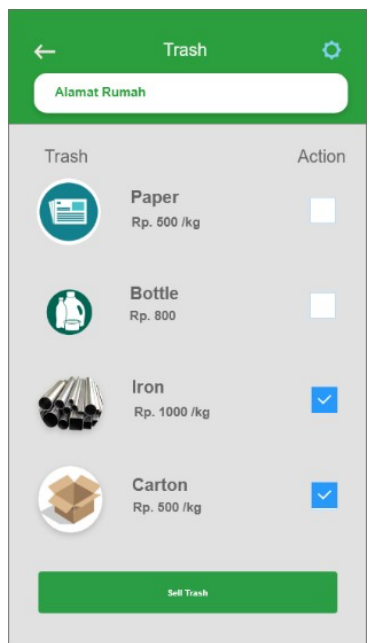

Gambar 8. Tampilan order menu inorganic

Pada halaman ini, user diminta untuk mengisi alamat user atau alamat pengangkutan. Kemudian memilih beberapa pilihan jenis sampah Inorganic yang akan diangkut. Setelah itu, akan diberikan informasi mengenai harga sampah yang akan diangkut. Jika user telah mengisi seluruh data pengangkutan maka user dapat mengklik tombol Sell Trash untuk mengorder driver dalam pengangkutan seperti pada Gambar 9.

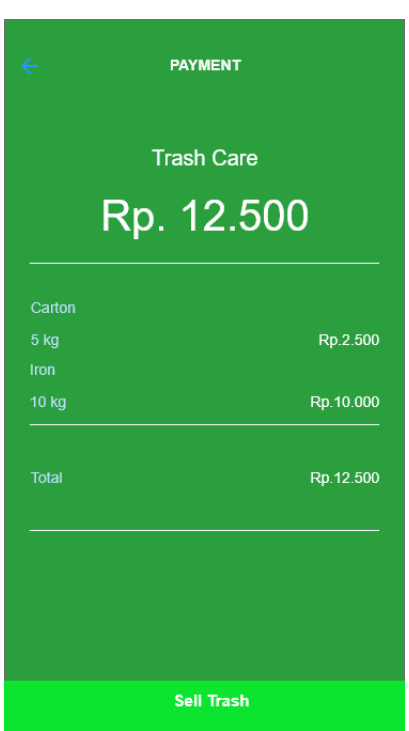

Gambar 9. Tampilan total pembayaran

Setelah itu, akan diberikan informasi mengenai harga sampah yang akan diangkut. Jika user telah mengisi seluruh data pengangkutan maka user dapat mengklik tombol Sell Trash untuk mengorder driver dalam pengangkutan.

Setelah melakukan transaksi Inorganic, maka saldo akan bertambah.

Jika user mengumpulkan jenis sampah organik dan ingin membuang sampah ke TPA maka user dapat memilih menu Organic. Berikut ini adalah tampilan pemesanan menu Organic.

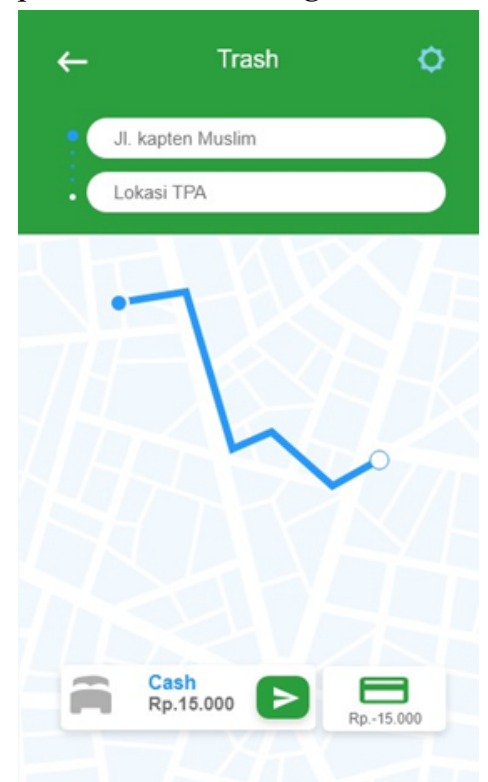

Gambar10. Tampilan pemesanan menu organic

Pada halaman ini, user diminta untuk memasukkan data pengangkuta berupa alamat pengangkutan dan alamat TPA yang dituju. Jika data pengangkutan 
telah diisi maka akan muncul informasi mengenai tarif pengangkutan. Taris yang dibayarkan dapat melalui uang tunai maupun saldo.

Informasi yang ditampilkan berupa harga yang dibayarkan, lokasi tujuan, jarak lokasi ke TPA, serta jangka waktu driver hingga sampai ke tujuan. Kemudian klik tombol ceklis untuk melakukan pemesanan.

Apabila user membayar pemesanan sampah organik melalui Wallet, maka diberikan tambahan informasi agar user dapat mengetahui besar biaya yang dibayarkan. Kemudian klik tombol ceklis untuk melanjutkan pemesanan seperti pada Gambar 11.

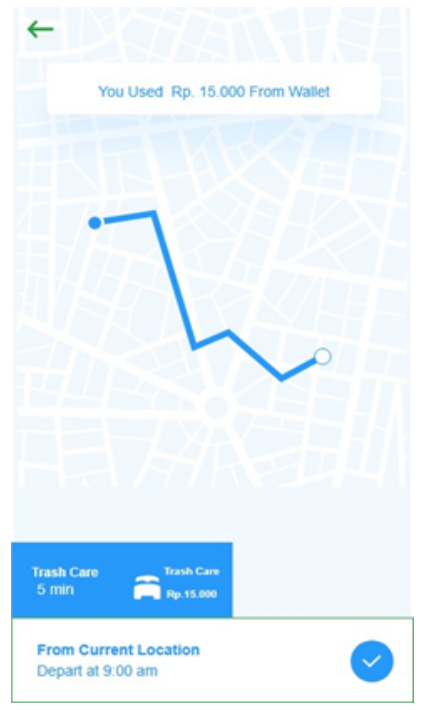

Gambar 11. Tampilan pembayaran dari wallet

b. Menu Picture.

Fitur Picture digunakan untuk memberikan informasi dari user kepada Dinas Kebersihan Kota Medan berupa gambar yang diambil secara langsung dan lokasi tempat penumpukan sampah.

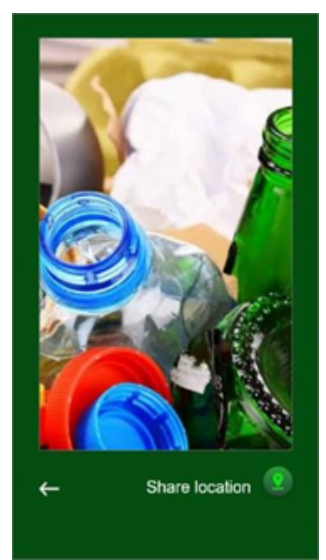

Gambar 12. Tampilan picture
Lokasi pada fitur Picture dapat ditentukan melalui titik koordinat yang telah di koneksi ke Google Maps. Saat user telah menentukan titik koordinat lokasi, maka user mengklik tombol kirim untuk mengirim informasi. Saat informasi telah terkirim, maka tampilan akan beralih ke halaman menu utama.

4. Tampilan Menu Setting.

Pada tampilan Menu utama terdapat tombol Setting yang berada di sudut kanan atas. Menu Setting berisikan identitas user yang telah diinput, beberapa pertanyaan dan informasi mengenai apa itu Trash Care.

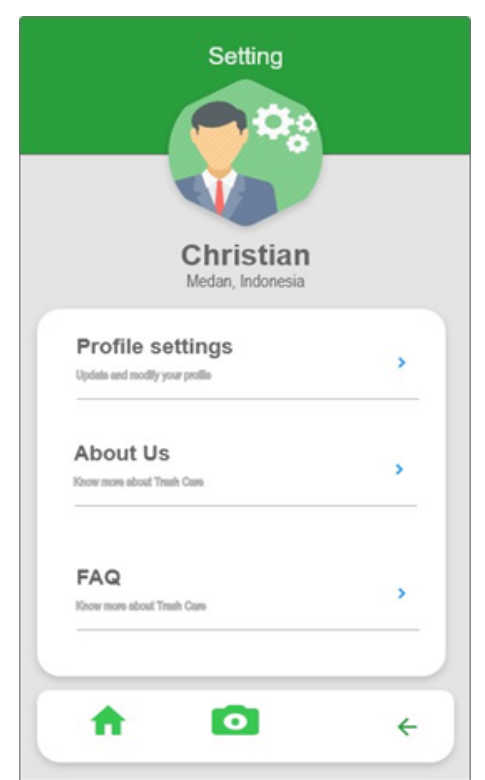

Gambar 13. Tampilan menu setting

\section{KESIMPULAN}

Kesimpulan dari penelitian ini adalah mendesain sebuah aplikasi berbasis android yang dapat membantu menanggulangi sampah dan dapat memberikan informasi kepada masyarakat mengenai jenis - jenis sampah. Desain aplikasi ini berfokus pada User Interface dan User Experience yang disesuaikan dengan kebutuhan pengguna yang dapat menarik minat masyarakat dalam membuang sampah menggunakan aplikasi ini. Aplikasi ini juga memiliki fitur Picture yang dapat membantu Dinas Kebersihan Kota Medan dalam menerima laporan mengenai lokasi penumpukan sampah. Perancangan desain aplikasi ini menggunakan Adobe XD CC.

Saran untuk penelitian selanjutnya diharapkan supaya tampilannya lebih menarik lagi dan mengkaji lebih dalam mengenai user interface dan user experience. Dan mengimplementasikan aplikasi ini dan dapat digunakan berbagai device. 


\section{DAFTAR PUSTAKA}

Naser, D. A. (2018). Perancangan user interface dan user experience halaman website program studi desain komunikasi visual universitas negeri padang. DEKAVE: Jurnal Desain Komunikasi Visual, 8(1), 1-23.

Rahayu, L. (2019). Dinas kebersihan kewalahan warga medan hasilkan sampah 2000 ton per hari: moda pengangkutan kurang. tribun-medan.com. Online. [Accessed: 30-Dec-2019].

Rianingtyas, A. K. dan Wardani, K. K. (2018). Perancangan user interface aplikasi mobile sebagai media promosi digital umkm tour dan travel. Jurnal Sains dan Seni ITS, 7(2), F-118F123.

Sulistiyorini, N. R. S., Darwis, R. S. \& Gutama, A. S. (2015). Partisipasi masyarakat dalam pengelolaan sampah di lingkungan margaluyu kelurahan cicurug. SHARE Social Work Journal, 5(1), 71-80.

Suriawiria, U. (1986). Mikrobiologi air dan dasardasar pengolahan buangan secara biologis. Skripsi. Bandung: Institut Teknologi Bandung. 